Jnl of Ecclesiastical History, Vol. 72, No. 3, July 202 I. $\quad$ (C) Cambridge University Press 2021 doi:10.1017/SoO22046921000622

\title{
The Eusebius Essay Prize The World Christianities Essay Prize
}

The Journal now offers two annual essay prizes of $£_{5}$ oo apiece. The Eusebius Essay Prize is awarded to the best essay submitted on a subject connected with any aspect of early Christian history, broadly understood as including the first seven centuries AD/CE. Scholars of any relevant discipline (theology, classics, late antique studies, Middle Eastern Studies etc.) are encouraged to enter the competition. The World Christianities Essay Prize is awarded to the best essay submitted on any aspect of the history of Christianity beyond Europe and North America since the year 700 , and is likewise open to scholars of any relevant discipline. Both competitions are open to scholars regardless of seniority, although submissions from junior scholars are particularly welcomed. Submissions for either prize should not exceed 8,ooo words, including endnotes. Submissions for the Eusebius Prize should be made by 30 September 2021: we would expect the winning essay to be published in the July 2022 number of the Journal. Submissions for the World Christianities Prize should be made by 31 March 2022: we would expect the winning essay to be published in the April 2023 number of the Journal. Other submissions entered into the competition may also be recommended for publication. The editors reserve the right not to award either prize if no essay of sufficient quality is submitted. All essays should be sent by email attachment (with the name of the relevant prize in the subject line), prepared to Journal style, to Mrs Mandy Barker at jeh@robinson.cam.ac.uk. 